\title{
PENGEMBANGAN PERPUSTAKAAN KAMUS DIGITAL DI ERA DIGITECH EDUCATION PADA MASA PANDEMI COVID-19
}

\author{
Cicik Tri Jayanti ${ }^{1}$, Lidya Amalia Rahmania ${ }^{2}$, Moh. Safii ${ }^{3}$ \\ ${ }^{123}$ Fakultas Sastra, Universitas Negeri Malang, \\ Email: ${ }^{1}$ cicik.jayanti.fs@um.ac.id, ${ }^{2}$ lidya.amalia.fs@um.ac.id, ${ }^{3}$ moh.safii@um.ac.id
}

\begin{abstract}
This study aims to develop a web-based digital dictionary library information system as an effort to increase the inventory of lexicography scientific cultural entries in the DigiTech Education era during the current COVID-19 Pandemic. This digital dictionary library information system is expected to be a means of archiving the archipelago cultural dictionaries created by students and can be widely accessed by people who need information related to the contents of the dictionary. It developed this digital learning model and digital content to improve the quality of learning quality, especially in Lexicography.
\end{abstract}

Keywords: a web-based digital dictionary library, cultural chemistry, Lexicography, DigiTech Education.

\begin{abstract}
Abstrak
Penelitian ini bertujuan untuk mengembangkan sistem informasi perpustakaan kamus digital berbasis web sebagai upaya meningkatkan inventarisasi lema kebudayaan keilmuan Leksikografi di era DigiTech Education pada Masa Pandemi Covid-19 saat ini. Sistem informasi perpustakaan kamus digital ini diharapkan mampu menjadi sarana pengarsipan kamus-kamus kebudayaan nusantara hasil karya mahasiswa serta dapat diakses secara luas oleh masyarakat yang membutuhkan informasi terkait dengan konten kamus tersebut. Model pembelajaran digital dan juga konten digital ini dikembangkan untuk meningkatkan mutu kualitas pembelajaran khususnya dalam keilmuan Leksikografi.
\end{abstract}

Kata Kunci: Perpustakaan kamus digital berbasis web, lema kebudayaan, Leksikografi, DigiTech Education.

\section{PENDAHULUAN}

Perkembangan teknologi informasi yang ikut menandai hadirnya Revolusi Industri 4.0 telah membawa dampak besar dalam berbagai bidang kehidupan. Tumpuan pada sistem fisik dan siber (cyber-physical system) sangat mempengaruhi cara kerja yang menuntut adanya kemampuan adaptasi dan kecepatan perubahan di era pembelajaran yang tidak dapat dilepaskan dari fasilitas pendukung teknologi digital (DigiTech Education) seperti saat ini (Saleh: 2010).

Terlebih pada masa pandemi covid-19 yang direspon cepat oleh Presiden, Menteri Pendidikan dan Kebudayaan, dan rektor Universitas Negeri Malang. Hal tersebut ditandai dengan dikeluarkan Temu Pewarta oleh Presiden RI, Joko Widodo pada tanggal 15 Maret 2020 tentang Taggapan Pemerintah Terhadap Pandemi Covid-19, Surat Edaran No 3 tahun 2020 tentang Pencegahan Penularan Covid-19 pada Satuan Pendidikan, dan Surat Edaran Nomor
27.3.3/UN32/TU/2020 tentang Perpanjangan Masa Pencegahan Penyebaran Virus Corona (COVID-19) di lingkungan Universitas Negeri Malang. Oleh sebab itu, perkuliahan diselenggarakan secara dalam jaringan (daring) dengan memanfaatkan keutamaan pembelajaran digital.

Pembelajaran digital merupakan salah satu pilihan dalam dunia pendidikan yang mampu memberikan akses pembelajaran yang mudah dan kilat. Pembelajaran digital dapat mewujudkan sistem pembelajaran terpusat yang dapat membangun relasi antarunsur yang terdapat dalam pendidikan sehingga sistem yang terjalin menjadi lebih revolusioner. Leksikologi merupakan cabang keilmuan bahasa yang mengandung kegiatan pengumpulan data, pilahan data, dan pendeskripsian satuan gramatikal terkecil atau kombinasi lema dalam mono-, bi-, atau multilingual. Leksikografi dapat diartikan sebagai cabang ilmu linguistik yang berkenaan 
dengan pembuatan kamus, sejak tahap perencanaan sampai dengan tahap penerbitan (Setiawan: 2015). Definisi tersebut memosisikan Leksikografi sebagai cabang keilmuan yang dikhususkan dengan prose pembuatan kamus (Chaer: 2007). Leksikografi tidak hanya meliputi kegiatan mengumpulkan lema dan menyusunnya berdasarkan urutan alfabetis sebagaimana anggapan umum, melainkan juga merupakan pengetahuan dan seni menyusun kamus-kamus bahasa secara sistematis untuk menghasikan produk kamus yang berkualitas (Kridalaksana: 2001).

Permasalahan yang dihadapi saat ini terkait keilmuan Leksikografi khususnya di lingkungan kampus adalah pola pengajaran dan output yang dihasilkan dari perkuliahan Leksikografi masih dilakukan secara manual dan minim melibatkan fasilitas yang berkaitan dengan digital elektronik. Mahasiswa peserta perkuliahan Leksikografi di akhir pertemuan hanya diwajibkan untuk membuat beberapa jenis kamus, baik itu kamus bahasa daerah, kuliner, dan hal-hal lain yang terkait dengan kebudayaaan nusantara, namun proses pengumpulan kamus tersebut hanya melalui file dalam bentuk softcopy maupun hardcopy kepada dosen pengampu perkuliahan. Kamus yang dikumpulkan tersebut nantinya hanya merupakan kumpulan file yang tidak terarsip dengan baik melalui database elektronik digital dan hanya dapat diakses oleh si pembuat dan dosen pengampu perkuliahan. Tentunya ini menjadi permasalahan dikarenakan kamus yang dibuat hanya digunakan sebagai formalitas untuk mendapatkan nilai matakuliah Leksikografi dan tidak dipublikasikan secara umum dengan tujuan pengembangan keilmuan.

Hal lain yang menjadi kendala mahasiswa adalah proses penyusunan kamus yang masih dilakukan secara manual dengan menggunakan aplikasi- aplikasi tertentu sehingga mahasiswa disibukkan dengan format tampilan grafis dan proses editing secara manual tanpa memperhatikan fokus konten/isi dari kamus yang telah disusun. Beberapa langkah dapat dilakukan guna memecahkan permasalahan tersebut, salah satunya ialah dengan mengembangkan sistem informasi pengarsipan kamus secara digital berbasis web dengan tujuan mempermudah proses editing/penyusunan, pengarsipan, dan publikasi kamus elektronik hasil karya mahasiswa yang dapat diakses masyarakat umum tanpa batasan waktu dan tempat (Supriyanto:2008 dan Pendit: 2007) Sistem informasi perpustakaan kamus digital berbasis web sebagai produk keilmuan Leksikografi diharapkan dapat menggantikan peran kamus yang disusun secara manual/cetak dikarenakan sifatnya yang dianggap lebih praktis dan fleksibel, lebih mudah diakses, lebih murah secara ekonomis bahkan dianggap lebih ramah lingkungan karena bersifat nirkertas (paperless) (Buxbhaum: 2004).

Berdasarkan aspek penyusunan, kemajuan teknologi informasi telah mengubah cara kerja manual ke arah serba otomatis sehingga meningkatkan efektivitas proses pembuatan/penyusunan kamus. Aspek penyusunan kamus meliputi pemanfaatan korpus, otomatisasi proses Leksikografis (penyuntingan), pengumpulan data melalui metode urun daya (crowd sourcing), dan hal-hal lain yang terkait pengembangan aplikasi DWS (dictionary writing system).

Di samping itu, berdasarkan aspek penggunaan, terlihat kecenderungan peralihan penggunaan format kamus cetak ke kamus elektronik (Mcclura:2017). Dengan format tersebut, dimungkinkan jangkauan pengguna informasi terkait kamus lebih meluas dengan cara yang cepat serta memungkinkan dikembangkan lebih lanjut dengan fitur-fitur lain yang bersifat user friendly sehingga memudahkan pemanfaatan sistem informasi perpustakaan kamus digital berbasis web dalam kaitannya dengan proses pembuatan kamus sebagai salah satu output perkuliahan Leksikografi.

\section{METODE DAN TINJAUAN PUSTAKA}

\section{Metode Penelitian}

Tahapan konsep pengembangan inovasi pembelajaran ini meliputi tahapan prapengembangan, tahapan pengembangan, dan tahapan pascapengembangan. Ketiga tahapan tersebut merupakan hasil modivikasi dari metode R\&D yang dicetuskan oleh Gall dan Borg (2003:569) yang mendefinisikan bahwa penelitian pengembangan di bidang pendidikan dan pembelajaran adalah sebuah proses yang memadukan produk dari hasil pengembangan dan validasi. Pada intinya, proses tersebut dijabarkan ke dalam tiga tahapan, yakni (1) prapengembangan, (2) pengembangan, dan (3) pascapengembangan.

Prapengembangan merupakan tahapan awal penelitian yang telah dilakukan oleh peneliti pada tahun 2019 dengan output berupa pengembangan kamus cetak kebudayaan 
nusantara sebagai luaran akhir perkuliahan Leksikografi. Hal tersebut dilakukan dengan melaksanakan identifikasi terhadap permasalahan yang terjadi di sekitar lingkup peneliti serta pencarian referensi yang berhubungan dengan pengembangan perpustakaan kamus digital berbasis web. Indikator capaian dari tahap ini adalah didapatkannya intisari rumusan masalah penelitian yakni belum adanya sistem informasi perpustakaan kamus digital di lingkungan Universitas Negeri Malang yang dapat difungsikan sebagai pengarsipan kamus dan media pembelajaran Matakuliah Leksikografi serta didapatkan beberapa referensi yang valid terkait dengan pengembangan dan perancangan perpustakaan kamus digital dalam bentuk publikasi ilmiah maupun buku cetak. Luaran dari tahapan ini yakni konsep pengembangan perpustakaan kamus digital berbasis web sebagai inovasi pembelajaran Matakuliah Leksikografi yang bersumber dari beberapa referensi antara lain publikasi ilmiah maupun buku cetak.

Pada tahapan pengembangan inovasi pembelajaran Leksikografi dilakukan dengan mengembangkan sistem informasi perpustakaan kamus digital berbasis web. Konten dari web ini meliputi sistem pengarsipan kamus kebudayaan nusantara hasil karya mahasiswa yang dapat diakses melalui internet. Kamus hasil karya mahasiswa tersebut diarsipkan menjadi beberapa kategori/katalog sesuai dengan pokok bahasan kamus, kemudian pengguna internet yang telah terotentifikasi dapat melakukan penambahan istilah-istilah baru ke dalam kamus yang telah dibuat sebelumnya, tentunya dengan sistem validasi lebih lanjut. Sistem informasi perpustakaan digital ini diharapkan dapat mempermudah akses bagi pengguna internet baik di kalangan mahasiswa internal maupun eksternal kampus guna menambah informasi terkait dengan keilmuan Leksikografi khususnya dalam hal pengembangan kamus.

Tahapan akhir dari pengembangan inovasi pembelajaran Leksikografi yakni tahap pascapengembangan. Pada tahap ini, hasil pengembangan kamus digital divalidasi oleh ketiga ahli, yakni (1) Bahasa, (2) Kamus, dan (3) Komputer. Ketiga ahli tersebut dipilih agar produk yang dikembangkan tidak hanya untuk menjawab permasalahan, melainkan juga merepresentasikan keilmuan bidang Leksikologi dan IT.

\section{Tinjauan Pustaka}

Beberapa penelitian terkait sistem perpustakaan digital dan pengembangan aplikasi kamus digital telah dilakukan oleh beberapa peneliti, antara lain Arya Wijaya, dkk (2015), Surya Atningsih, dkk (2017), Tri Listyorini, dkk (2015), dan Nasrul Nawaei, dkk (2017). Penelitian yang dilakukan oleh Arya Wijaya, dkk (2015) berjudul "Pembuatan Aplikasi Perpustakaan Digital Online Berbasis SaaS". Desain perpustakaan digital pada penelitian ini menggunakan aplikasi berbasis Software as a Services (SaaS). Aplikasi tersebut dikhususkan membaca e-book tanpa harus menginstal aplikasi tersebut pada perangkat keras/gadget yang digunakan. Teknologi perpustakaan digital ini menggunakan cloud computing sehingga developer dapat menciptakan aplikasi tanpa harus terlebih dahulu meng-instal aplikasi tersebut (Wijaya:2015).

Kajian berikutnya adalah penelitian dengan judul "Perancangan Sistem Informasi Perpustakaan Digital Berbasis Web" yang ditulis oleh Suria Atsiningsih, dkk (2017). Penelitian ini merancang sebuah sistem informasi perpustakaan digital berbasis web yang dapat menghadirkan fitur berbagi sumber sehingga memungkinkan user untuk saling membagi file yang nantinya akan menolong perpustakaan dari minimnya jumlah buku atau pustaka. Dari hasil pengembangan yang dilakukan, web perpustakaan digital ini dirasakan lebih mangkus dan sangkil dalam mendukung laju informasi serta memenuhi luaran perpustakaan untuk menebar pengetahuan. Metode yang diterapkan untuk pengembangan software ini menggunakan model waterfall / sekuensial linier dan peralatan pendukung UML. Fitur resource sharing yang digunakan pada sistem informasi ini memungkinkan untuk memiliki koleksi pustaka yang lebih banya dan bervariatif dari berbagai referensi serta memungkinkan pembaca koleksi perpustakaan digital memberikan kontribusinya sekaligus peluang untuk memperoleh keuntungan dari dokumen yang dibagikan kepada pengguna lain (Atningsih:2017).

Penelitian yang digunakan sebagai referensi berikutnya dilakukan oleh Tri Listyorini, dkk (2015) berjudul "Pengembangan Digital library Berbasis Web Responsive". Perpustakaan digital sebagai output yang dihasilkan pada penelitian ini adalah perpustakaan digital e-book berbasis web responsive yang dapat diakses dimanapun tanpa harus datang ke perpustakaan. Pengembangan 
web responsive ini ditopang oleh metode air terjun yang diasumsikan sebagai pendekatan kuno dalam penelitian terkait pengembangan sistem. Langkah-langkah yang dilakukan yakni proses pemilihan $e^{-}$book, scanning dan penyeragaman nama referensi. Hal ini ditujukan untuk mempermudah pencarian buku. Penelitian ini juga memperhitungkan kompresi data yang digunakan dalam proses editing referensi. Aplikasi ini dapat diakses dengan menggunakan server yang bersifat local/local host dengan memanfaatkan IP address apabila menggunakan fasilitas LAN yang terkoneksi langsung dengan internet cable (Lastyorini: 2015).

Penelitian berikutnya berjudul "Rancangan Pembangunan Web E-Library Pada Perpustakaan Aptikom Indonesia Berbasis Web" yang ditulis oleh basuki rahmad, dkk, (2013). Metode yang digunakan dalam melaksanakan kegiatan penelitian ini dilakukan dengan beberapa langkah, antara lain : pencarian literatur terkait dengan perancangan web (MySQL dan PHP), perancangan sistem dan model relasi berdasarkan tabel-tabel database, serta dilakukan observasi terhadap hasil rancangan web dengan menggunakan internet atau jaringan. Hasil dari penelitian ini disimpulkan bahwa aplikasi ini mampu menolong pihak perpustakaan untuk efisiensi pengorganisasian pustaka, pendataan member mahasiswa, serta perekaman pinjam secara daring dikarenakan bersifat paperless dan terkomputerisasi melalui database web (Rahmad: 2013).

Berdasarkan hasil uraian di atas, hasil penelitian terkait perpustakaan digital sebagian besar hanya membahas terkait dengan database pada e-book, namun belum spesifik mengarah pada database kamus digital sebagai bagian dari referensi bahasa dalam keilmuan Leksikografi. Perancangan perpustakaan digital berbasis web terbukti mampu membantu dalam hal pencarian data maupun referensi. Data hasil penelitian di atas menjadi dasar bagi peneliti untuk mengembangkan model inovasi pembelajaran perpustakaan kamus digital berbasis web dalam perkuliahan Leksikografi sehingga diharapkan model inovasi pembelajaran ini mampu meningkatkan kualitas pembelajaran serta mempermudah mahasiswa dalam memanfaatkan web sebagai media pembelajaran berbasis Student Centered Learning (SCL).

\section{HASIL DAN PEMBAHASAN}

1. Prapengembangan Perpustakaan Kamus Digital Berbasis Web Sebagai Media Inventarisasi Lema Kebudayaan di Era Digitech Education pada Masa Pandemi Covid-19

Eksplorasi terhadap kebutuhan perpustakaan kamus digital berbasis web dilakukan terhadap empat objek. Keempat objek tersebut, yakni (1) telaah kurikulum, (2) wawancara kepada dosen dan mahasiswa, (3) telaah pustaka untuk dijadikan dasar teori pengembangan produk, dan (4) telaah penelitian terdahulu. Berdasarkan hasil analisis kebutuhan yang telah dilakukan, maka dikembangkan Perpustakaan Kamus Digital Berbasis Web dengan memperhatikan hal-hal sebagai berikut:

a. Perpustakaan Kamus Digital yang dikembangkan dapat digunakan untuk pembelajaran matakuliah leksikologi dan penyusunan kamus pada masa pandemi covid 19.

b. Perpustakaan Kamus Digital yang dikembangkan memuat layanan penyedia kamus digital, yaitu (1) pencarian, (2) tambah lema, (3) baca, (4) cek input, (5) dan unduh.

c. Perpustakaan kamus digital yang dikembangkan memuat fitur layanan penulisan kamus terbuka, yaitu (1) kosakata, (2) pelafalan, (3) kelas kata, (4) makna atau arti kata, (5) realisasi kata, (6) korpus sebagai bukti keberadaan, (7) unggah gambar, dan (8) sumber gambar.

d. Perpustakaan kamus digital yang dikembangkan berbasis web.

e. Perpustakaan kamus digital yang dikembangkan memuat buku panduan yang dapat memudahkan pengguna dalam mengoperasikan.

\section{Pengembangan Perpustakaan Kamus Digital Berbasis Web Sebagai Media Inventarisasi Lema Kebudayaan di Era Digitech Education pada Masa Pandemi Covid-19}

Pengembangan web kamus terdiri atas tiga, yakni (1) pengembangan kamus mentah, (2) pengembangan web, dan (3) desain hosting. Ketiga tahapan tersebut dapat dijabarkan sebagai berikut:

\section{a. Pengembangan Kamus Mentah (Offline)}

Pada tahapan ini, dihasilkan 9 kamus secara offline, yakni (1) kamus kuliner Jawa Timur, (2) 
Kamus Kuliner Sambal Nusantara, (3) Kamus Mistik Kejawen, (4) Kamus Istilah Pertanian, (5) Kamus Pusparagam Kain Indonesia, (6) Kamus Tanaman Herbal, (7) Kamus Makanan Upacara Adat Jawa Timur, (8) Kamus Hantu Nusantara, dan (9) Kamus Random.

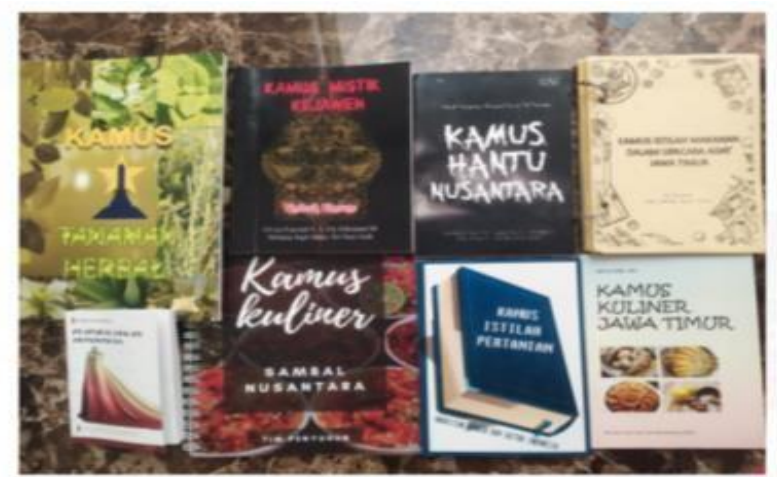

Gambar 1. Kamus Manual Kebudayaan Indonesia

\section{b. Pengembangan Web}

Pada tahapan ini dilaksanakan koding oleh ahli IT sesuai spesifikasi produk yang dikembangkan peneliti. Berikut merupakan susunan folder koding yang dirancang ahli IT untuk mewadahi kamus web sesuai spesifikasi produk yang diajukan.

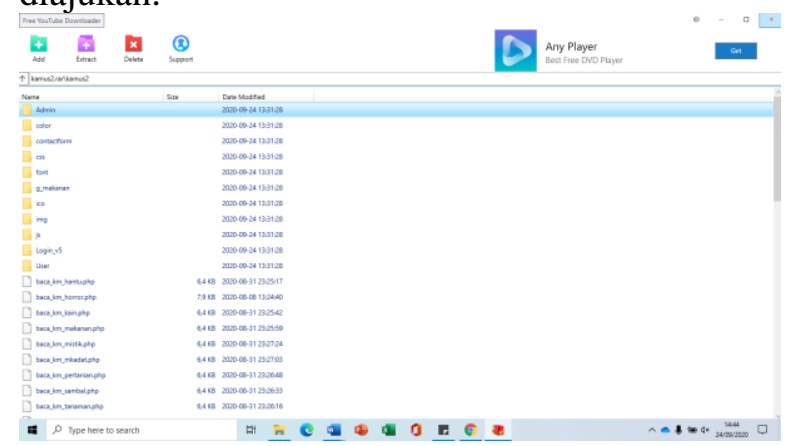

Gambar 2. Koding Layar Utama

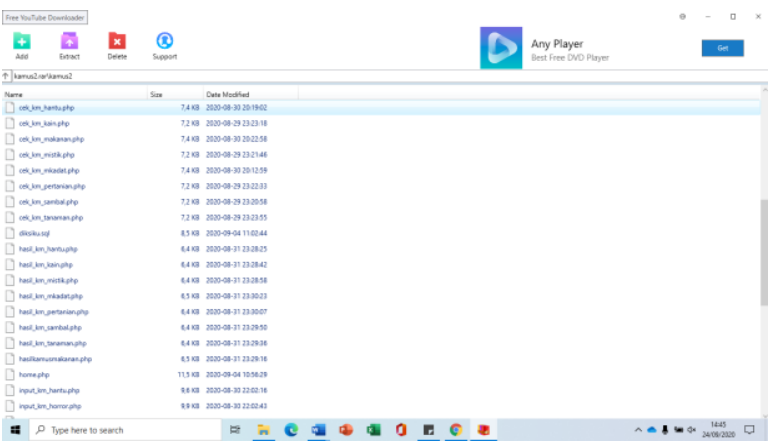

Gambar 3. Koding Fitur Tambahan

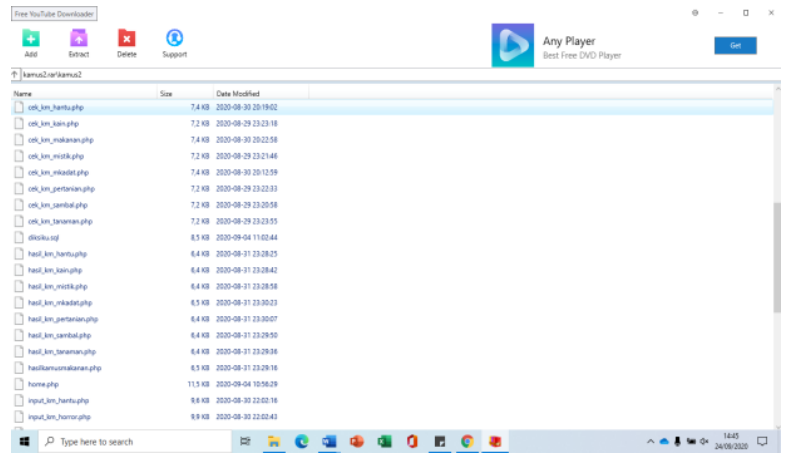

Gambar 4. Koding Masing-Masing Kamus

Adapun piranti lunak yang digunakan pada pengembangan kamus web ini ialah XAMPP versi 7.3.12 dengan server web tipe Apache tingkat 2.4.41, PHP versi 7.4.1., data dasar tipe MySQL versi 8.0.18., proses pengorganisasian gambar ditunjang aplikasi Adobe Photoshop CS5, proses pengorganisasian script menggunakan teks pengedit yaitu notepad++ versi 7.8.2, serta menggunakan browser Google Chrome.

\section{c. Desain Hosting}

Setelah file local host sudah dirancang dalam bentuk koding PHP, kamus web dirupakan menjadi laman yang dapat diakses melalui saluran internet secara real time. Adapun hasil dari tahapan ini ialah alamat laman .com, tepatnya http://diksiku.com/ sebagai berikut.

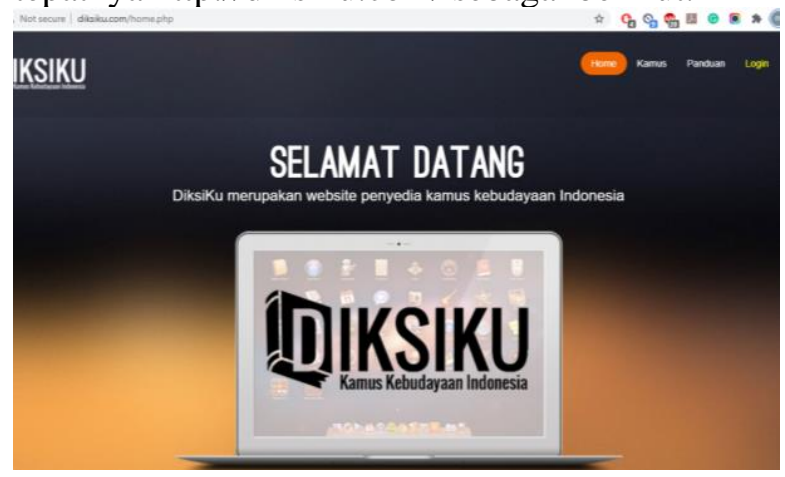

Gambar 5. Hasil Hosting Alamat Diksiku

\section{Pascapengembangan Perpustakaan Kamus Digital Berbasis Web Sebagai Media Inventarisasi Lema Kebudayaan di Era Digitech Education pada Masa Pandemi Covid-19}

Tahap pascapengembangan yang meliputi uji ahli dan uji lapangan. Pertama, uji ahli. Ahli yang dimintai masukan terkait pengembangan web kamus ini meliputi, (1) ahli Bahasa, (2) ahli kamus, dan (3) ahli multimedia. Ketiga ahli tersebut memberikan penilaian terkait beberapa kriteria yang sesuai dengan kepakaran masing- 
masing. Pertama, ahli bahasa meliputi kriteria seputar aspek: (1) keterbacaan, (2) tata bahasa, (3) ejaan, (4) istilah, (5) struktur kalimat, dan (6) kegramatikalan Bahasa pada tampilan. Kedua, ahli kamus meliputi kriteria seputar aspek: (1) sajian kosakata, (2) pelafalan, (3) Kelas Kata, (4) Makna Kata, (5) realisasi kata, (6) korpus, (7) gambar, dan (8) sumber gambar. Ketiga, ahli multimedia meliputi pertanyaan seputar aspek: (1) tampilan, (2) pemilihan warna, (3) kontras warna, (4) keselarasan warna latar dengan konten, (5) kesesuaian fungsi, (6) fitur dengan isi, (7) pemilihan huruf, (8) tidak terlalu mencolok, (9) keterbacaan san serif, (10) percabangan fitur, (11) kemudahan akses (dari segala hal), dan (12) beraturan dengan kuota kecil.

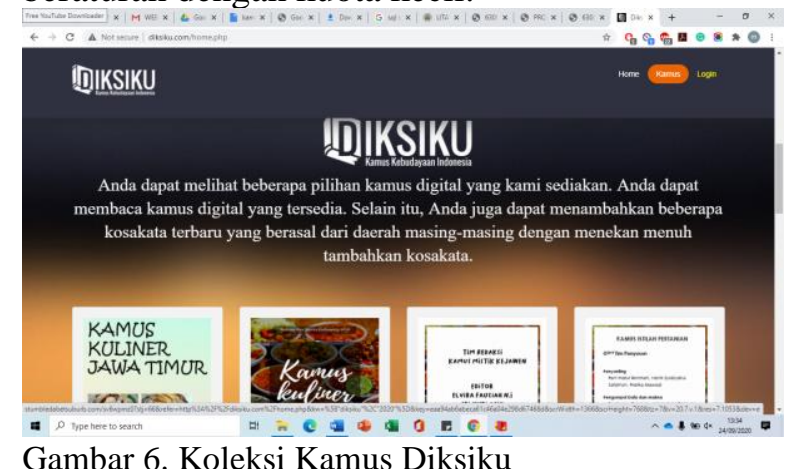

Sebelum menetapkan simpulan hasil, data diolah menggunakan rumus penggolongan menurut Sudjana (2010:45). Berikut merupakan rumus yang digunakan untuk mengolah data persentase.

$\mathbf{P}=\sum \mathbf{x} \sum \mathbf{x i} \times \mathbf{1 0 0 \%}$

Keterangan:

P : Persentase skor akhir hasil keseluruhan validasi ahli

$\sum \mathrm{x} \quad$ : Jumlah keseluruhan jawaban validator ahli dalam kesemua kriteria penilaian

$\sum x i$ : Jumlah keseluruhan skor maksimal validator ahli dalam kesemua kriteria penilaian

$100 \%$ : Konstanta Agar simpulan terhadap hasil analisis persentase tingkat kelayakan media lebih mudah diperoleh, ditetapkan kriteria penggolongan menurut Arikunto (2018:246) yaitu:

Tabel 1 Analisis Persentase

\begin{tabular}{ll}
\hline Skor Persen & Keterangan \\
\hline 80 hingga 100 & Valid/digunakan \\
\hline 60 hingga 79 & Cukup valid/digunakan \\
\hline 50 hingga 59 & Kurang valid/direvisi \\
\hline Kurang 50 & Tidak valid/direvisi \\
\hline Sumber: Arikunto & $(2018: 246)$
\end{tabular}

Berdasarkan validasi dari ketiga ahli, Kamus Digital Berbasis Web yang dikembangkan menunjukkan kategori valid. Hal tersebut diketahui dari ketiga perolehan berturutturut dari (1) ahli Bahasa, (2) ahli kamus, dan (3) ahli multimedia yang memberikan persentase $81 \%, 85 \%$, dan $90 \%$. Ketiga persentase perolehan tersebut menunjukkan bahwa tindak lanjut media latih ini ialah implementasi.

\section{SIMPULAN}

Berdasarkan pengembangan ini, ditemukan bahwa Kamus Digital Berbasis Web untuk perkuliahan Leksikologi dan Penulisan Kamus dibutuhkan oleh dosen dan mahasiswa di era pandemi Covid 19 ini. Perpustakaan Kamus Digital Berbasis Web ini terdiri atas (1) kamus kuliner Jawa Timur, (2) Kamus Kuliner Sambal Nusantara, (3) Kamus Mistik Kejawen, (4) Kamus Istilah Pertanian, (5) Kamus Pusparagam Kain Indonesia, (6) Kamus Tanaman Herbal, (7) Kamus Makanan Upacara Adat Jawa Timur, (8) Kamus Hantu Nusantara, dan (9) Kamus Random. Kesembilan kamus tersebut menunjukkan kriteria valid dan dapat digunakan dalam perkuliahan Leksikologi dan Penulisan Kamus. Hal tersebut diketahui berdasarkan hasil validasi terhadap ketia ahli, yakni (1) ahli Bahasa, (2) ahli kamus, dan (3) ahli multimedia.

\section{DAFTAR RUJUKAN}

Arikunto, Suharsimi. 2018. Prosedur Penelitian Suatu Pendekatan Praktik. Jakarta: PT Asdi Mahasatya.

Atningsih, Suria dan Sugiarto, Hari. 2017. Perancangan Sistem Informasi Perpustakaan Digital Berbasis Web. Indonesian Journal on Networking and Security, ISSN: 2354-6654. Volume 6, No. 4.

Buxbhaum, S. 2004. Library Services: Perpustakaan Virtual untuk Kuliah Bisnis Sistem Jarak Jauh, Tren yang Berkembang Saat Ini. Jakarta: PT. Rajagrafindo Persada.

Chaer, Abdul. 2007. Leksikologi dan Leksikografi Indonesia. Jakarta: Rineka Cipta.

Kridalaksana, Harimurti. 2001. Kamus Linguistik. Jakarta: PT Gramedia Pustaka Utama. 
Listyorini, Tri, dan Iqbal, Mohammad. 2015. Pengembangan Digital Library Berbasis Web Responsive. Konferensi Nasional Sisten dan Informatika, ISSN: 24608378.

Mechura, Michal. 2017. Introducing Lexonomy: an open-source dictionary writing and publishing system. Czech Republic: Natural Language Processing Centre.

Pendit, Putu Laksman dkk. 2007. Perpustakaan Digital: Perspektif Perpustakaan Perguruan Tinggi Indonesia. Jakarta: CV Sagung Seto.

Rahmad, Basuki, dan Purnama, Bambang. 2013. Rancangan Pembangunan Web E-Library Pada Perpustakaan Aptikom Indonesia Berbasis Web. Seminar Riset Unggulan
Nasional Informastika dan Komputer, ISSN: 2302-1136, Vol: 2, No. 1.

Saleh, Abdul Rahman. 2010. Membangun Perpustakaan Digital. Jakarta: CV Sagung Seto.

Setiawan, Teguh. 2015. Leksikografi. Yogyakarta: Penerbit Ombak

Sudjana, Nana dan Ahmad Rivai. 2010. Media Pengajaran. Bandung: Penerbit C.V. Sinar Baru Bandung.

Supriyanto, Wahyu. 2008. Teknologi Informasi Perpustakaan. Yogyakarta.

Wijaya, Arya. 2015. Pembuatan Aplikasi Perpustakaan Digital Online Berbasis SaaS. e-Proceeding of Applied Science, ISSN 2442-5826, Vol.1, No.1. 
Volume 6 No. 2 METALINGUA

Oktober 2021 Jurnal Pendidikan Bahasa dan Sastra Indonesia 